Social Dynamics

\title{
The Quest for Healing in South Africa's Age of AIDS
}

\section{Nicoli Nattrass}

To cite this article: Nicoli Nattrass (2005) The Quest for Healing in South Africa's Age of AIDS, Social Dynamics, 31:2, 1-23, DOI: 10.1080/02533950508628706

To link to this article: http://dx.doi.org/10.1080/02533950508628706

曲 Published online: 11 Aug 2008.

Submit your article to this journal $\pi$

Џll Article views: 102

Q View related articles $\asymp$

4 Citing articles: 3 View citing articles 


\title{
The Quest for Healing in South Africa's Age of AIDS
}

\section{Nicoli Nattrass}

\begin{abstract}
Highly Active Antiretroviral Therapy (HAART) is the most effective means of extending the lives of people living with AIDS - yet only $25 \%$ of those in South Africa estimated to need it are receiving HAART. Those who cannot access HAART (or choose not to take it) may opt to use 'traditional' healing instead. Some people will do both. This article reviews the emerging South African literature exploring the interface between biomedical and traditional healing in this age of AIDS. It includes a discussion of recent relevant biographies and books. Particular attention is paid to the contrasting experiences of Edwin Cameron who took HAART and continues to live a productive life, and Fana Khaba, who rejected HAART in favour of untested substances. The paper notes how the diagnosis of AIDS as being caused by witchcraft may have psychological benefits (it shifts blame and responsibility to others) it can also exacerbate social tensions and undermine the health of those living with AIDS. It is argued that the state has an obligation to provide information to AIDS patients about the best scientifically tested medications.
\end{abstract}

\section{Introduction}

South Africa has many dubious records with regard to AIDS. It has the greatest number of HIV-positive people in Sub-Saharan Africa, and with the possible exception of India, more HIV-positive people living within its borders than any country on earth. More optimistically, South Africa has, with the help of non-governmental organisations and donor agencies such as the Global Fund and PEPFAR, one of the largest treatment programmes to provide highly active antiretroviral therapy (HAART) to people living with AIDS. South Africa is probably now second only to Brazil in terms of absolute numbers of people on HAART (Nattrass, 2006c). But HAART 
coverage (that is, the proportion of people needing treatment who are actually receiving it) remains relatively low because South Africa still tops the chart for having the greatest unmet need for HAART $(866,000$ people as of June $2005)^{1}$ (Nattrass, 2006a). Despite the rapid growth in numbers of people on HAART in 2004 and 2005 (see Figure 1), South Africa's rollout has performed poorly in comparison to both South Africa's own 2003 Operational Plan (DOH, 2003) and to other countries (Nattrass, 2006a).

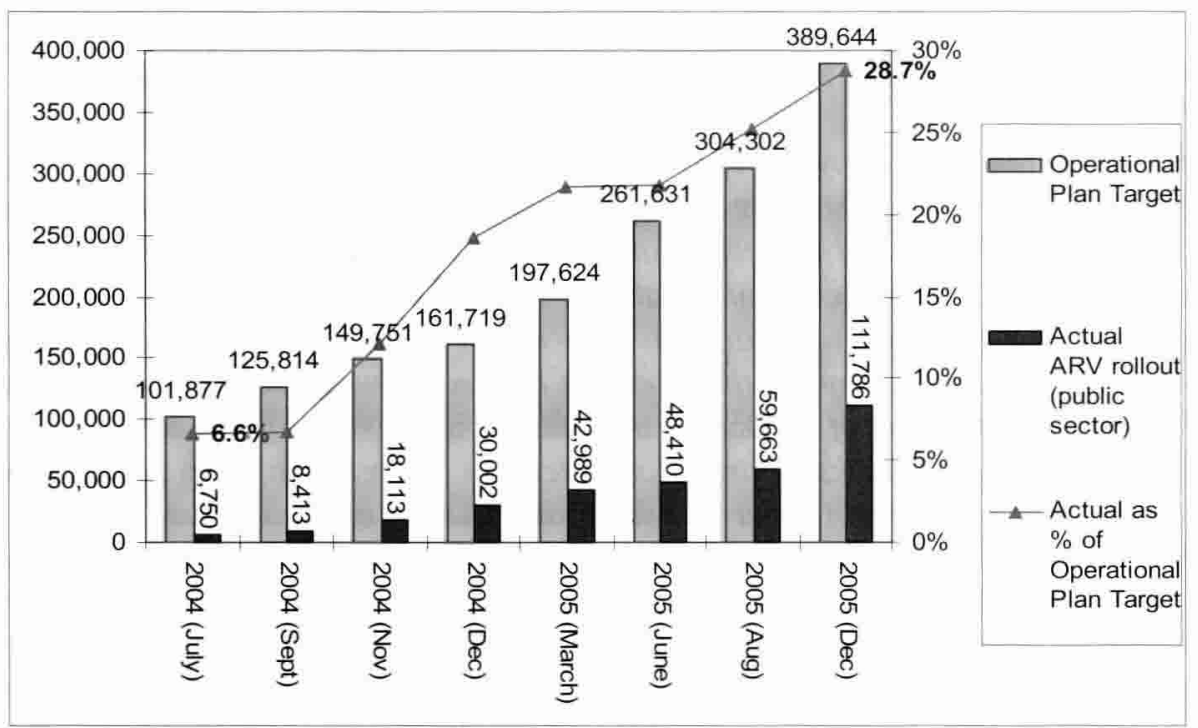

FIGURE 1: Growth in the Number of People on HAART in the South African Public Sector

Source: Nattrass (2006c).

As of December 2005, only about a quarter of the number of people needing HAART were receiving it - and even in the best performing province, the Western Cape, HAART coverage had reached only 55\% (Nattrass, 2006c). What this means in practice, is that many people who are sick with AIDS either do not have access to a HAART rollout site, or are being discouraged from taking HAART - perhaps by the Health Minister's many references to antiretrovirals as 'poison' (Nattrass, 2006b). Many of these people will instead seek the healing services of traditional healers and 'alternative' therapists selling scientifically unproven substances as remedies for AIDS. 
Of course the search for healing is far more complex a phenomenon than a simple function of the local availability of HAART and the confusion over its therapeutic benefits. For those who, as Adam Ashforth (2005a) puts it, 'live in a world with witches', their affliction with AIDS may well be taken as a sign of bewitchment. As discussed in more detail below, the symptoms of AIDS and the fact that bodily fluids are involved in transmitting the virus, resonate powerfully with local understandings of pollution and witchcraft as underlying health problems (Ashforth, 2005a, 2005b; Wreford, 2005a; Henderson, 2005). People suffering from AIDS may thus opt to consult both traditional healers such as sangomas (or 'isangoma' if the Zulu form is used) who specialise in combating witchcraft and they may also seek the help of Western biomedicine.

There is an emerging literature which explores the search for healing at the interface between scientific 'biomedicine' providing antiretrovirals and alternative therapies - especially traditional healing services provided by African spiritual healers who invoke the power of ancestors to assist with the diagnosis and treatment of illness and misfortune. This paper reviews the themes evident in some of this literature (published here in this special issue of Social Dinamics). It also includes a review of recent biographies of South Africans who have adopted diverse healing strategies in this age of AIDS.

Before proceeding, it is worth reflecting briefly on the intellectual problem of how to frame the relationship between traditional / alternative healing systems on the one hand, and biomedicine on the other. Medical historians and anthropologists of Africa have, for the past two decades, been strongly influenced by 'social constructivism' which emphasises that medicine is a highly specialised domain of social practice and discourse (Wright and Teacher, 1982). At the heart of the social constructivist project is the insistence "that there is room for a variety of interpretations and meanings, that behind consensus or "knowledge" lie social processes, and that such processes involve negotiations and conflict, both overt and implicit' (Jordanova, 1995: 368). Historians have, accordingly, emphasised the role of biomedicine as a tool of colonial subjugation (Vaughan, 1992) as well as the discursive/political strategies employed by biomedicine and the indigenous strategies of resistance (including selective incorporation) against it.

But while this is a useful lens for looking at aspect of medical history, it is a narrow one which deflects attention away from issues of class, politicaleconomy and the social production of disease itself (Marks, 1997: 215). Furthermore, as Vaughan points out, although biological fact cannot be 
disassociated from the cultural metaphors/fictions within which it is expressed, it is not always appropriate to go so far down the road of social constructivism as to render biology totally passive (1994: 285-7). She reminds her readers that the colonial campaign against yaws was effective (see Ranger, 1981) even if others, such as attempts to control the 1918 flu epidemic were not.

The issue of medical efficacy poses problems for social constructivists who all too easily fall into a relativist position which sees biomedicine as but one particular form of culture. This has had a widespread impact on medical historians who take great pains to avoid being accused of 'whiggish' or 'triumphalist' histories of medical science. Even Roy Porter, the most prolific and iconoclastic historian of medicine, felt compelled to justify his magnum opus on medical history by pointing out that biomedicine has delivered some benefits (for example, developing insulin for treating diabetes) and observing (tellingly) that 'one can study winners without siding with them' (1997: 12). Perhaps this urge to justify highlighting the successes of biomedicine arises from the revulsion towards medical science and scientific power that is evident in the work of Foucault (Jordanova, 1995: $368-9$ ). Or perhaps it stems from a concern not to appear to be participating in some broader ideological project which glosses over biomedicine's debts to medical folk-lore and obscures the role and social importance of alternative/traditional medicine.

Whatever the reason, adopting a relativist position towards biomedicine in today's age of AIDS is fraught with ethical difficulties. Medical historians are in the luxurious position of being able to focus on whatever dimensions of medical history they choose. For those writing about the period prior to the invention of antibiotics (biomedicine's most important advance), the issue of the relative efficacy of biomedical and other healing strategies was an open question. However, the AIDS pandemic represents a very different stage in medical history. Not only is HAART demonstrably capable of saving and extending lives (see Cascade Collaboration, 2006 for recent evidence), but there is a massive international effort in progress to extend access to HAART in developing countries. The greater the number of AIDS-sick people who can be placed on HAART, the better. Traditional / alternative healers, if they are to assist with the saving of life, need to work with this biomedical advance - not against it.

This is not to say that traditional healing has no value for customers. As many scholars have pointed out, traditional/alternative practitioners may 
be able to provide services that are psychologically soothing to clients (perhaps because they appear to adopt a 'holistic' approach) and which are understood to be more culturally appropriate (see, for example, Digby and Johansson, 2003). They may even be able to contribute to the production of new biomedicines if traditional treatments are found to be effective - although it is worth noting at this point that no traditional medicine has been found to be effective against HIV/AIDS, and there are serious concerns about adverse reactions between traditional herbal remedies and antiretroviral therapy (Mills et al., 2003). The point is simply that adopting a neutral or relativist stance towards traditional and biomedicine is inappropriate if the objective is to save lives.

The challenge for scholars writing about the here and now is to gain a better understanding of the quest for healing in South Africa's age of AIDS, and for those of us who are interested in policy conclusions - think about how best to respond. For this reason, several papers in this volume (Mills, 2005; Wreford, 2005b, Devinish, 2005) grapple explicitly with the issue of regulating traditional medicine and possibly fostering collaboration between biomedical and traditional healing practitioners. This, however, is inevitably a fraught process as it has to confront the role of science as arbiter of efficacy (Geffen, 2005; Ashforth, 2005a, 2005b).

\section{Overview of the Emerging South African Literature}

This special issue begins with a rich anthropological account by Henderson (2005) of two traditional healers from rural KwaZulu Natal, one of them an inyanga (herbalist), the other an HIV-positive sangoma (diviner) who is herself HIV-positive and on HAART. Henderson describes how they were called to become healers, explores their approach to treating AIDS, and touches on local explanations for the AIDS pandemic. She describes their ambivalence towards modernity and argues that this reflects their specific social history and marginalised rural location.

Henderson provides a fascinating account of how the military metaphors which often surface in AIDS treatment and prevention discourses resonate with local understandings. Thus, the immune system is known as 'the soldiers of the body', and a CD4 cell count of 30 is understood as the person having only 30 soldiers left in the body. Both of the healers she interviewed accept that neither traditional nor biomedicine has a cure for AIDS. But they recognise that biomedicine has provided medication that can suppress the 
effects of the virus and prolong life. The sangoma reports that the ancestors which guide her ('ancestral shades') tell her that AIDS is a 'new illness' and that they cannot help her cure it.

Wreford (2005a) likewise cites a sangoma saying that AIDS is a 'modern' illness for which the ancestors do not have a cure. However, as she goes on to show, not all sangomas adopt this line. Some of them continue to claim that AIDS can be cured, and in one instance that Wreford analyses, the practitioner argues against the use of HAART. As a practising sangoma and anthropologist, Wreford is well placed to explore the ambiguities and tensions involved at the interface between biomedicine and traditional healing. Wreford pays particular attention to ambiguities and differences of understanding between biomedical practitioners and traditional healers with regard to the notion of 'cure'. She notes that traditional healers typically regard the absence of symptoms as being 'a cure'. Thus, if patients suffering from AIDS-related opportunistic infections become better under their care, the traditional healer may, mistakenly but in good faith, believe the patient to be cured, even though the cure relates only to the opportunistic infection rather than the underlying condition (HIV infection).

This is something that can be addressed through training. In Henderson's study (2005), both traditional healers had received AIDS training. As a result, the sangoma argued that antiretroviral 'pills' had to be taken every day, because if the patient does not, they will create a 'treacherous donga [ravine or gully] in which the virus will rise up and increase'. Wreford is in favour of AIDS training for traditional healers, but notes her concern that this is often a one-way street, with traditional healers feeling that their skills are inadequately appreciated.

This theme is explored in more detail by Wreford (2005b) who presents a literature survey of collaborations between western and traditional healers with regard to AIDS interventions. She argues that collaboration between traditional healers and conventional health practitioners is both possible and desirable. However, Mall's (2005) research note on her preliminary study of attitudes on the part of conventional health practitioners towards the involvement of sangomas in AIDS care, suggests that this will not be easy. In this sense, it complements the argument made by Wreford in both her papers about the scepticism on the part of conventional health practitioners. Mall points out that not only are conventional health practitioners doubtful about the potential for collaboration, but they are also 
(justifiably) worried about the possible toxic effects of traditional or other non-scientifically tested medicine (and its interactions with HAART).

One of the interesting aspects of Mall's study is her reference to the potential role of HIV-positive sangoma in bridging the divide between traditional and western biomedicine. Mall reports that doctors hope that traditional healers, who themselves are on HAART, will develop a set of healing strategies for their HIV-positive patients that will complement rather than undermine the HAART regimen. Given Henderson's (2005) account of the HIV-positive sangoma who argues stridently in favour of adherence to HAART, such optimism is perhaps well founded. Working with HIV-positive inyanga and sangoma who are also HAART patients may well be a fruitful template for collaboration.

Mills (2005) provides further insight into the world view of sangoma with her case study vignettes of sangomas involved in treating people with AIDS in Cape Town. She begins her paper with a discussion of the quest for healing by Nana, a young HIV-positive woman from Khayelitsha, Cape Town. Mills tells the story of her journey from consulting a sangoma to eventually going on antiretroviral treatment (as part of the first pilot HAART project offered in South Africa by Medicines Sans Frontiers in partnership with the Western Cape Provincial Government). Although it was the latter that proved to be successful at controlling her illness, she nevertheless retains an ambiguous position vis-à-vis traditional medicine - saying that sometimes she believes in sangomas, sometimes not. This is entirely consistent with the general ambiguity that Ashforth (2005a) describes in his Soweto study towards witches, witchcraft and traditional healing.

Nattrass (2005) continues this patient-centred perspective with an empirical analysis of who consults sangomas in Khayelitsha. After discussing the difficulties in measuring instances of demand for the services of such traditional healers, the paper outlines a few statistical regularities. For example, those who visit sangomas are less likely to report that 'people in general can be trusted'. Again, this is consistent with Ashforth's (2005a) argument that those who consult sangomas because they suspect their afflictions are caused by witchcraft, are living in a spiritually insecure world in which anyone is capable of jealousy, envy and thereby mobilising occult forces against others. Henderson's (2005) account of rural discourses of marginalisation and the belief that AIDS was deliberately created to harm Africans by jealous white people similarly highlights the role of material and spiritual insecurity in shaping and maintaining such views on the world. 
Although traditional healing is an important counter-weight to biomedicine, it is not the only one. As Geffen (2005) shows, the government's support for alternatives to HAART extends beyond traditional healing and into the realm of 'pseudo-science'. By this, he means the production of medicines in direct competition with HAART, but which have not been tested scientifically. He pays particular attention to the Health Minister's support for 'pseudo-science', and in particular, her apparent support for Mattias Rath who advocates the use of micronutrients instead of HAART. Geffen's analysis highlights the importance of scientific testing and warns of the dangers of side-lining science (as illustrated by Lysenkoism in the Soviet Union in which the adoption of pseudo-scientific biological theory contributed to the collapse of agriculture). Whilst sympathetic to traditional healers, Geffen argues that their medicines also need to undergo scientific testing.

Ashforth (2005b) also focuses on the role of science and the challenges posed by alternative (whether 'traditional' or otherwise) therapies. He focuses specifically on the notion of 'African science' and indigenous knowledge systems and the challenges that this poses for the regulation of traditional/ alternative medicine. He points out that the discourse of African science not only seeks to provide a scientific basis for African healing practices - but simultaneously also contributes to the plausibility of suppositions about the abilities of persons to cause harm to others through witchcraft. He provides a critical history of the notion of 'indigenous knowledge systems' as a political construct in South Africa, highlighting the contradictions and ambiguities for the modern political state in managing it.

The theme of regulation of health practitioners operating outside the remit of conventional science is taken further by Devinish (2005) who explores the history of organisation of traditional healers in Natal. She points to the parallels between this process of professionalisation and that undertaken by biomedical practitioners, although in the case of traditional healers, the historical outcome was far less successful. In addition to pointing to the unequal relationship between professional biomedicine and traditional healing, Devinish highlights the tension between sangomas and inyangas when it comes to organisational dynamics. Inyangas, by virtue of the fact that they sell medicinal herbs, are closer to conventional health practitioners than the spiritual healing practices of sangomas. This makes inyangas easier to professionalise. 
Whereas Henderson (2005) and Wreford (2005a) appear to accept without question the claims by inyangas and sangomas that they are not motivated by income-earning concerns, Devinish observes that an important incentive behind professionalisation and regulation by traditional healers is to protect their activities from newcomers and to gain access to resources from the state. Both Wreford and Henderson describe how sangomas go through a period of ill-health when being 'called' to become a healer, and how they are guided by ancestors rather than a profit motive. Ashforth, however, is more sceptical, and points to the role of this period of sickness as being an ideological devise to free the healer from the taint of being engaged in income-earning activities. Given that sangomas claim to derive their healing powers from the ancestors, any implication that they are simply in it for the money, that is, are 'charlatans', threatens to undermine their businesses.

Those who promote healing strategies in opposition to HAART need a legitimating framework outside of conventional science. This can either be an appeal to higher spiritual authority (as is the case with sangoma) or it can rest on a critique of science itself. Thus, in the case of Matthias Rath, his case rests on an AIDS dissident/denialist claim that the conventional science on AIDS has been corrupted by the large pharmaceutical companies seeking to make money out of the suffering of others (Nattrass, 2006b; Geffen, 2005). Such a stance is, of course, deeply ironical because the Rath Health Foundation is itself a pharmaceutical industry seeking to profit from AIDS. In seeking to construct his own legitimacy, Rath has mobilised support from the Traditional Healers Association by harnessing their ambivalence towards the orthodox and seemingly all-powerful biomedical paradigm. However, as Geffen shows, Rath himself has a powerful political ally in the person of South Africa's health minister. The notion that scientifically tested treatment strategies are thus always necessarily supported by government must thus be carefully qualified.

The emerging literature discussed here highlights complexity and ambiguity rather than any bi-polar 'western' versus 'traditional' medicine. As shown in Nattrass (2005), there is a great deal of evidence that patients are active participants in their own healing strategies, and that their chosen course of action' depends on the type of illness being experienced. This is illustrated vividly by Mills' account of Nana's quest for healing. Although traditional healing is sought for specific problems such as bewitchment, this does not preclude people from simultaneously seeking the assistance of biomedicine. It is not as if the patient is trapped in either a 'traditional' or a scientific 
paradigm. People move freely between the two in search of improved health. For most illnesses, their first port of call is western biomedicine.

Likewise, the healers themselves are not rooted in any one fixed healing culture, but draw on their own experiences and adapt to the environment they work in. This is why, as Devinish and Ashforth explain, they are difficult to organise and professionalise. It is also why some of their healing products are difficult if not impossible to test scientifically. Whilst there may be a case for creating enabling legislation to facilitate the work of 'traditional' healers, this is likely to be difficult (if not impossible) to operationalise. And if space is created for alternative traditional remedies, then space is also created for rival pharmaceutical enterprises like the Rath Health Foundation which markets 'alternative' or complementary products.

The essence of the problem is that in today's economically integrated and commercialised world, AIDS patients are consumers of health products and healers are producers of health services. A government that seeks to facilitate an 'African' traditional or 'alternative' healing sector outside the remit of scientific regulation thus faces the danger of turning traditional medicine into a Trojan horse for all purveyors of unproven substances. In so doing, it runs the danger of failing its citizens who desperately need good guidance as to how to overcome this dreaded, 'new' disease, AIDS.

Ashforth and Nattrass (2005) argue that two contrasting cultural strategies are evident to promote adherence to HAART: The TAC's Treatment Literacy Programme which seeks to educate people into a conventional scientific understanding of HIV disease and treatment; and a Department of Health Voluntary Counseling and Testing (VCT) video which harnesses putative 'indigenous knowledge' relating to illness and healing. They argue that the latter strategy risks connecting with fears regarding the 'African science' of witchcraft and that this can serve to confuse, rather than clarify, ambiguities concerning the notion of 'cure'. Science education is challenging, but has the potential to empower patients to manage their illness effectively.

\section{Contrasting Biographies on Treating AIDS in South Africa}

In 2005, four books were published on health-seeking strategies in this age of AIDS in South Africa. Two were autobiographical accounts by white men 
describing how they came to terms with their HIV diagnosis and went onto antiretroviral therapy (Cameron, 2005; Levin, 2005). The other two books dealt with the quest for alternative forms of healing by African people. McGregor (2005) provides an account of a man (Fana Khaba) who rejected HAART, and died after taking a series of 'traditional' and quack remedies. Ashforth (2005a), the most academic and rigorous book of the quartet, shows that for the many people who live in a world with witches, healing strategies inevitably entail encounters with occult forces. The article by Ashforth in this special issue (Ashforth, 2005b) is drawn from this book.

The accounts by Cameron and McGregor illustrate the two extreme ends of the AIDS healing continuum: the willing embrace versus the hostile rejection of antiretrovirals. In his book, A Witness to AIDS, Edwin Cameron describes how he had to overcome a strong sense of self-stigmatisation as part of a journey involving disclosing his HIV status and going onto HAART. As a consequence of being the only HIV-positive high-profile office holder in South Africa, he also had to learn how to function simultaneously as a judge whilst also undertaking what he believes to be a moral duty to be a 'witness' to AIDS and advocate for HAART. Cameron is particularly concerned about the links between AIDS treatment and inequality. He stresses the fact that when he went on HAART in 1997, he was one of the very few South Africans rich enough to afford it. For him, this was reprehensible, and the key reason why he felt the need to enter the public battle for wide-spread access to HAART.

Cameron's book skilfully weaves together his personal narrative with rich detail (provided in part by contributions from Geffen) about how antiretroviral treatment works, and the many obstacles to wider-spread access - including the issue of patent protection, ongoing stigma and the problem of AIDS denialism (which he likens to holocaust denialism). Cameron argues that there is 'a distinctive form of African AIDS denialism' that is rooted in a discourse of race and sexual shame. Referring to speeches by South African president Mbeki and to a document distributed within the structures of the African National Congress (ANC), Cameron argues that the essence of African AIDS denialism is that belief in the conventional predicates of epidemiology and disease management as they apply to AIDS in Africa is racist because it proceeds from the premise that HIV is mostly sexually transmitted' (Cameron, 2005: 98). As Cameron writes, the denialist view that antiretrovirals are at best unnecessary and at worst outright poison "has not only re-stigmatised our understanding of the disease, but ... has 
disempowered our understanding of our own capacity, as Africans, to intervene with immediate efficacy to stop appalling suffering. Science, and reason, enable us to do better' (ibid: 121).

It is a book which unashamedly celebrates science, and the demonstrable healing powers of HAART. He uses his life story as a canvas to paint a vivid picture of how HAART can succeed in restoring a person's immune system, thereby giving him or her back that most precious of commodities, life. For Cameron, the provision of HAART through the public health sector is a human right and 'must be the starting point of any rational, humane, response to the epidemic' (ibid: 93). His description of the impact of HAART on his health is worth quoting in detail. After outlining the unpleasant side effects, including gastric problems and ultra-sensitive teeth, he writes:

But all this was quite trivial besides the growing realisation that something quite unmistakably dramatic was taking place within my body. My tiredness was lessening. It was disappearing. In its place, I could feel a daily access of miraculous new energy. Life forces were coursing through my body. Illness was yielding to a nearly novel feeling - renewed and joyful wellbeing.... I not only regained my appetite - despite the nausea the protease inhibitors induced when I took them, I became ravenously and continuously hungry. For the first time in months, my stomach was digesting food properly. And my gaunt body avidly claimed every morsel of it to make up for the twelve kilograms (twenty five pounds) in weight I had lost.

There was only one word for it. It was glorious. The drugs were working. I could feel that I was getting healthy again. I knew that I would be well again. That, in turn, spurred my inner confidence. Physiological wellbeing had a pronounced psychic effect. If the drugs were working - and it was utterly clear they were - it meant that for the first time since my infection more than twelve years before, the virus was no longer multiplying within me. It was no longer progressively taking over my body, taking over my life. It was being beaten back to some deeply secluded (although latently dangerous) viral reservoirs. But outside these recesses, the rest of my body was free of it. And my immune system was, for the first time in all these years, free of its burdens.

The feeling was exhilarating. For the first time in more than a decade I was no longer - no longer felt - contaminated. From the world I had little to hide, and less to fear. (ibid: $38-9$ ).

McGregor's book Khabzela is about Fana Khaba, a popular Johannesburg DJ who rejected HAART and died of AIDS after a fruitless search for successful alternative healing. By contrast to Cameron's, this is a depressing story of treatment failure. It is also unlike Cameron's powerful autobiography in that it is written from the uncomfortable perspective of an 
outsider who readily admits that she does not understand the person she was writing about (McGregor met Khaba only a couple of times) and did not enjoy the co-operation of his family in the writing of her book. Nevertheless, McGregor struggles gamely with her subject, and whilst admittedly failing to provide a convincing account of why he chose the healing strategies that he did, she succeeds in painting an eye-opening picture of the kind of world those who reject the science of AIDS and AIDS treatment find themselves in.

McGregor's account of Khaba is a telling counterweight to Cameron's book. Like Cameron, Khaba was a high-profile person with celebrity status who chose to disclose his HIV status publicly. Shortly after learning, in May 2003, that he was sick with AIDS, Khaba announced over the radio that he was HIV positive, telling his listeners that he was going to have to take time off to recover. The response of listeners was overwhelmingly supportive, as was the studio management at $\mathrm{Yfm}$ radio. In this respect too, Khaba's story closely resembles that of Cameron who also discovered unexpected reservoirs of support from those around him. Although Khaba (who was known as 'Khabzela' to his listeners) was an independent contractor and not on medical aid, the station offered to continue to pay his salary, pay his medical expenses and keep his radio slot open until he returned. The studio management expected him to go home, begin HAART and record his progress in an audio diary. Y fm, with its 1.8 million listeners, hoped to become the first broadcaster in South Africa to host a regular show on living positively with HIV. They expected that Khabzela, like Cameron, would become an icon for living positively with the illness that was affecting so many young people.

But unlike Cameron, Khaba rejected HAART on the grounds that antiretrovirals were likely to kill him, and launched himself instead on a desperate search for healing which took him from one unsuccessful alternative therapist to another. This story is fascinating for what it reveals about the murky world of alternative practitioners acting beyond the remit of scientific regulation. Consider, for example, 'Dr Irene', an uneducated sixty-two year old white woman from Brakpan, who (according to Khaba's fiancé) strongly encouraged Khaba to take her 'Amazing Grace' pills rather than antiretrovirals. These pills, which are manufactured using 'supermarket ingredients' and divine inspiration, sell for R100 a course (or R140 if the individual wants the pills couriered to them). If it is true, as Irene claims, that 2,000 people (90 percent of whom are black) are currently taking her Amazing Grace pills, then this suggests a monthly turnover of at least 
R200,000. Even after deducting wages for the six people she employs (which include an 'AIDS counsellor' and several lay pastors who dispense the pills with a prayer), this no doubt leaves her with a sizable profit.

In addition to opening a window on this world of minor charlatans, McGregor's book is interesting also for the insight it provides into the active support by the Minister of Health (Dr Manto Tshabalala-Msimang) for Tine van der Maas. Van der Mass is a retired Dutch nurse who sells a nostrum called 'Africa's Solution' as an AIDS remedy and recommends that people fight HIV through diet rather than through antiretroviral therapy. 'Africa's Solution' comes in liquid form and the label on the bottle (in the ANC colours of gold green and black) says that it contains inter alia African potato extract, olive green leaf extract, vitamins and grapefruit seed extract. The bottle also advises patients to take two crushed cloves of garlic a day and to eat one cup of pronutro (a South African cereal).

Van der Maas has collaborated with Kim Cools, a Belgian AIDS dissident acting under the auspices of a NGO called 'African Rainbow Circle'. Cools runs an organic commune in Natal on a piece of prime land allocated to him by the local chief after he promised to eradicate AIDS from the area. Operating under the protection of the chief, he tells people not to take antiretrovirals but instead rely on lemon juice and olive oil. This has, according to the head of the AIDS outreach program in Inanda, posed challenges for the HAART rollout because 'most people there are illiterate and very gullible, especially if it's a white man' (quoted in McGregor, 2005: 228). Van der Maas told McGregor that the Health Minister had visited their Natal project twice and that this was the reason 'why she keeps on saying lemons and garlic because she has seen it work' (ibid: 219).

McGregor reports that the Health Minister phoned Khaba's mother in October 2003 to tell her that she was sending van der Maas to help them. Even though Khaba's CD4 count was two at the time (that is, his immune system was very seriously compromised or, as Henderson's sangoma would say, he had only two soldiers left in his body), van der Maas claimed that she could treat him, saying 'He doesn't want ARVs. I say to him it is not necessary' (quoted in ibid: 17). Khaba, by this time, was simply too desperately ill to be treated by nutritional interventions alone. McGregor describes how when van der Maas gave him a drink made of liquidised beetroot, olive oil, ginger, carrots, tomatoes, spinach, lemon juice olive oil, pawpaw, watermelon, banana, yoghurt and pronutro, Khaba promptly vomited it up. 
Khaba died three months later, his body wasted and in agony, aged thirty-five. In contrast to Cameron's joyous endorsement of HAART, McGregor writes:

Fana Khaba died a horrible death. The HI virus had destroyed his brain, leaving him demented and hallucinatory. He could no longer move his arms or legs. He could neither defecate nor urinate. The colostomy bag attached to his bowel to drain his waste was leaking blood. Pus seeped from the wound left by the operation to remove his intestines. A vast bedsore had eaten away his right buttock. More bedsores festered on his back, hips, ankles and elbows.

It must have been a relief to him when, at 12.10 on January 14,2004 , he finally stopped breathing. (ibid: 7).

If the Health Minister, instead of actively supporting an alternative remedy of unproven benefit, had instead encouraged Khaba to take his antiretrovirals, the outcome would almost certainly have been very different. Thamm, writing for a weekly woman's magazine in South Africa made the point very bluntly by comparing Khaba's story to that of Adam Levin, a young white man whose autobiography (Levin, 2005) came out at the same time as McGregor's book:

Both men had dangerously low CD4 counts of only two when they were diagnosed. Adam immediately went on a cocktail of antiretrovirals. Today he is in his late $30 \mathrm{~s}$. He still suffers, but he writes prolifically, he earns a living, he parties, he eats and drinks, he goes out with friends, and yes, he even occasionally has sex. Fana was black, Adam is white. Fana pinned all his hopes of recovery on the minister of health's Dutch quack. Adam took antiretrovirals. Fana Khaba is dead. Adam Levin is alive. Who killed Fana Khaba? (Thamm, 2005)

As indicated in this rather blunt challenge, there is a high-stakes battle on the go over the use of antiretroviral medication - a battle in which science itself has become politicised, and racialised. Many people are being caught between conventional scientific solutions (HAART) and so-called 'African' solutions which the Health Minister promotes and which do not appear to be being held to the same level of scientific testing as conventional medicines (Nattrass, 2006b; Geffen, 2005). Although support for alternative therapies is often couched in an Africanist discourse (see, for example, DOH, 2006), the battle is far from being a simple struggle between an 'African' versus a 'Western' way of healing. As documented by McGregor (2005) and Geffen (2005), the dissident alternative practitioners supported by the Health Minister included Dutch (Tine van der Maas), German (Matthias Rath) and Belgian (Kim Cools) entrepreneurs. McGregor comments on this in her conclusion: 
What puzzles me is the collection of dodgy Europeans who appear to have been given succour by [Mbeki's] minister of health..... How does this square with the African Renaissance? Does all one have to do to gain credence is attach the work African to something: African potato? Africa's Solution? African Rainbow Circle? (McGregor, 2005: 244).

Cameron's answer to this, as indicated earlier, is to locate the problem not within the context of two rival health approaches in which one is labelled 'African' and the other 'Western' but rather to suggest that the appeal of AIDS dissident alternative therapists is that their diagnosis and solutions deflect attention away from the role played by sexual behaviour in driving the AIDS epidemic. Not only does this remove the aspersions that may be cast on African sexual culture for facilitating the epidemic, but it also serves to remove the psychological burden of having to take responsibility for becoming infected, for practising safe sex so as not to infect others in the future, and to subject oneself to a life-long, discipline of taking chronic medication twice a day.

\title{
Deflecting Blame and Seeking Cures
}

Adam Ashforth argues that for many Africans there is a powerful association between AIDS and witchcraft. He points out that the common symptoms of AIDS, such as persistent coughing, diarrhea, abdominal pains and wasting "have long been associated in this part of the world with the malicious assaults of witches' (2005a: 9). Similar arguments are made by Wreford (2005a) and Henderson (2005). One of the most common forms of witchcraft is idliso (commonly translated as 'poison') in which the witch manufactures a creature that manifests itself in the body of the victim in a form usually resembling a snake or lizard. This creature which brings misfortune to the victim whilst devouring him or her from within. Ashforth notes that:

\begin{abstract}
AIDS-awareness accounts of HIV as an invisible agency inhering in the already potentially dangerous mess of bodily fluids that is the medium of exchange of sex resonate powerfully with local understandings of invisible agents involved in witcheraft that contaminate a victim and then begin to 'attack' the victim by destroying the person's defences, precipitating illness, misfortune and death. The language of 'attack' and 'defence' common in virology and AIDS awareness discourses in precisely the same language used in describing the actions of poison and poisoners spoken of as 'witchcraft' (2005a: 9-10).
\end{abstract}

But as Ashforth points out, 'awareness of AIDS as an incurable disease brought on by an invisible virus, rarely suffices to make sense of the suffering and death it occasions' (2005a: 107). For those who live in a world 
with witches, the question inevitably arises of who is to blame for the misfortune. Ashforth argues that living in a world with witches is to live in a world of spiritual insecurity in which misfortune can be traced to the envy and jealousy of neighbours, family-members, lovers or workmates. He links the widespread perception of increased incidence of witchcraft to rising income inequality and unemployment in post-apartheid South Africa. In Ashforth's account, it is this rising inequality that is putting strains on norms of reciprocity and patterns of redistribution, giving rise to envy and resentment, which in turn results in misfortune and ill health. Interestingly, the sangoma described by Henderson (2005) also attributes the AIDS epidemic to postapartheid jealousy, but instead of locating it in the context of patterns of redistribution within African society, locates the problem as being one of white jealousy because of the shift to a universal franchise. The implication here is that whites were responsible for the witcheraft that caused AIDS.

As Ashforth notes, 'Life in a world with witches must be lived in the light of a presumption of malice: one must assume that anyone with the motive to harm has access to the means and that people will cause harm because they can'. It is thus 'wise, when misfortune does occur, to inquire into who might be responsible, if for no other reason than to afford protection against further mishap' (Ashforth, 2005a: 69).

In his preliminary 'sociology of jealousy', Ashforth observes that some relationships are more prone to jealousy than others, and thus more susceptible to witchcraft. Chief amongst these relationships is that between lovers and spouses. He points out that 'when a man dies, his wife will automatically be suspected of killing him' even if the immediate cause of death was something unconnected with the wife, such as a car crash (ibid: 74). This was precisely what happened to Khaba's fiancé, Sibongile. This is what she told McGregor:

If a man passes away, it's a big issue. People start saying you are responsible for his death. When you pass away, they say 'ag, its Gods will'. Look at my case. Everything was okay. All of a sudden, Fana starts getting ill and things turn sour. It happens to people who had something while they were living, like say, they had businesses. The family always feels that they have the rights over whatever it is that he owned or worked for. They feel that you are nothing. You are not their child; you are not their sister. It has happened in my family. My family has done it to other people. That is why it was maybe easier for me to deal with because it happens every day in our culture.

In Fana's case it was worse because he was ill and everybody knew what was wrong with him. But still they said he was bewitched (McGregor, 2005: 177-8). 
The conflict between Khaba's fiancé and his family deepened to such an extent that he was eventually removed from her care and she was barred from attending his funeral. Her blame for his predicament was facilitated by an sangoma who told Khaba's family that 'a woman was behind this' (ibid: 176). As Ashforth notes, "when people begin to wonder whether witcheraft is affecting their fortunes, they have access to innumerable healers willing to endorse and enflame their suspicions' (Ashforth, 2005a: 62).

This raises the deeply ambiguous notion of the African 'healer'. On the one hand, the sangoma is 'healing' the evil effects of witchcraft, but on the other hand, he or she may well be causing social disruption in the process. The actions of sangoma are far from neutral - as is clear from the above discussion with regard to gender relations as women are more easily blamed for misfortune than men. Likewise, work relationships can suffer. As McGregor reports, Khaba initially believed that he had been bewitched at work by a colleague, something that his manager found very tricky to deal with.

Furthermore, sangomas and inyangas themselves can contribute to the climate of fear and suspicion. Although they speak a discourse of healing, rather than perpetrating, witchcraft (Henderson, 2005; Wreford, 2005a), 'the popular supposition is that those who know how to use substances (muti) and rituals to heal, probably also know how to use the same to cause harm' (Ashforth, 2005a: 59). The dread of the healer as a potential purveyor of witchcraft is clear in McGregor's account of Khaba's fiancé:

Sibongile shuddered when she talked about the Khaba family. 'Jesus, they hated me so much, it scared me. I was thinking: 'Where did that come from? What did I do that was so horrible?' I was scared for my own life. Those inyangas they go to; they can get some muti for me. Because that's what they believe in, so why wouldn't they do that to another person? (McGregor, 2005: 176).

Living in a world with witches is clearly a fearful experience. But it also has the psychological advantages for the individual of blaming others for his or her predicament. Having AIDS is thus not seen as the result of one's own failure to practice safe sex - but it is the fault of someone else - someone who had set out to cause you harm. Such a blame-free account is evident from one of the sangomas that Khaba consulted on his quest for healing. McGregor visited the sangoma, who called himself 'Mr Magic' with one of Khaba's friends (Satch) who acted as a translator. Although this sangoma did not blame Sibongile outright, he still attributed Khaba's illness to the malevolent intent of a woman. 
'What happened', explained Satch, 'is that there was a certain lady who played as if she liked Fana and he got hooked and she gave it to him. That is where he contracted this poison'.

'Through sex?' I asked.

'No', said Satch. 'Somebody can give it to you without having it. They can buy it and bring it to a place where you pass every day and they call your name. It is like a speed trap. You can't see it but it can catch you. And even if thousands of people pass that place where it is, because your name was called, it will catch you and go into your body. You can only feel it after two or three months but then it's gone into your body. But he can help you out of it', said Satch, nodding at Mr Magic, who frequently interjected and corrected the narrative (McGregor, 2005: 204).

The idea that getting AIDS is like a speed trap put there not to catch speedsters, but rather put there by someone deliberately seeking to harm you, clearly has its psychological compensations. It lifts responsibility from the person's shoulders for causing his or her own harm - and for causing harm to others (through practising unsafe sex and infecting others, as Khaba did his fiancé).

The other psychological 'advantage' of this healing paradigm is that it holds out the possibility of a cure. As Ashforth writes:

There are no limits to the possible use of muthi other than the skill and supernatural connections of the person making and using it. Witches using muthi are said to be able to cause every disease and misfortune under the sun. Healers claim to be able to cure every disease (including AIDS, though many know better than to mention this to outsiders now) and to remedy every misfortune ever suffered (2005a: 134).

Understood in these terms, then, an appealing way of dealing with AIDS is to seek the most powerful healer and get cured. On the one hand, this is a very empowering strategy. According to McGregor, this was one of the motives behind Khaba's rejection of antiretrovirals: 'Acknowledging how ill he was and submitting to the treatment required to make him well would have required a temporary surrender of his independence, a reversion to an infantile state' (McGregor, 2005: 160). His decision to reject chronic medication and seek a cure, by contrast, put him back in the driving seat: 'Once again, there were people fawning over him. He had power. He could make a healer famous by trying out his or her cure' (ibid: 161).

Wreford (2005a) makes a similar argument when discussing the case of an HIV-positive nurse who when learning that she was HIV-positive, sought out a traditional healer who told her that someone had 'poured' the disease on her. The nurse took the traditional healer's treatment and reported 
that she was now 'better'. Wreford argues that what is at stake here is the 'question of personal agency in the face of a death-bringing illness'. The nurse's biomedical training would have alerted her to the nature of HIV and to the life-prolonging impact of HAART. But this meant also confronting the fact that she had an incurable disease, thereby rendering her powerless to change that. The witchcraft explanation, by contrast, offered the possibility of healing.

Unfortunately, rejecting the scientific explanation of AIDS and of best practice therapy is simultaneously deeply disempowering because the patient cannot know if the alternative remedy will work until they have tried it. And, given the long progression from HIV-infection to AIDS with its accompanying shifts in health status, it is very difficult for patients to know whether the reason why they are feeling 'better' had anything to do with the treatment they received. This can be a very expensive business as people shift from one healer to the next. Ashforth reports the case of Themba, whose fruitless search for a cure for AIDS took him from one traditional healer to the next. According to one of his friends, by the time Themba 'finally succumbed to the virus, almost R40,000 had been wasted seeking a cure' (quoted in Ashforth, 2005a: 108).

\section{Conclusion}

This brings me back to the theme with which I concluded the first part of this review essay: in today's integrated economic world, healers are entrepreneurs and patients are customers. Individual healing journeys through the forest of rival healing practitioners can be a dangerous and expensive business. Patients, as citizens, should be provided with the best available information by the government. This is why it is one of the important functions of the modern state to ensure the scientific regulation of medicines. People are obviously free to pursue whatever healing strategies make sense to them. However, in the interests of saving lives (and of preventing the wasteful expenditure of income on ineffective remedies), the state has a moral duty to inform people about the scientifically-proven benefits of HAART. 
Nicoli Nattrass is professor in the School of Economics at the University of Cape Town (UCT) and director of the AIDS and Society Research Unit (ASRU) within the Centre for Social Science Research (CSSR) at UCT. She is the author of The Moral Economy of AIDS in South Africa and has completed several other publications that analyse issues related to HIV/AIDS, including the disability grant tradeoff, access to antiretroviral treatment etc. See www.cssr.uct.ac.za for more details. She lectures the 'Economics of AIDS in Sub-Saharan Africa' master's level course, amongst others, at UCT. Her email address is nnattras@commerce.uct.ac.za.

\section{References}

Ashforth, A. 2005a. Witchcraft, Violence and Democracy in South Africa, Chicago: Chicago University Press.

Ashforth, A. 2005b. Muthi, Medicine and Witchcraft: Regulating 'African Science' in PostApartheid South Africa?, Social Dynamics, 31(2): 211-242.

Ashforth, A. and N. Nattrass. 2005. Ambiguities of Culture and the Antiretroviral Treatment Rollout in South Africa, Social Dynamics, 31(2): 285-303.

Cameron, E. 2005. Witness to AIDS, Cape Town: Tafelberg.

Cascade Collaboration. 2006. 'Effective therapy has altered the spectrum of cause-specific mortality following HIV seroconversion', AIDS, 20(5): 741-9.

Devenish, A. 2005. 'Negotiating Healing: Understanding the Dynamics amongst Traditional Healers in Kwazulu-Natal as they Engage with Professionalisation', Social Dynamics, 31(2): 243-284.

Department of Health (DOH), 13/2/06, 'DA undermines Indigenous Knowledge'. Available on http://www/doh.gov/za/docs/pr/2006/pr0213.html

Digby, A., and Johannson, S. 2003. 'Producing Health in Past and Present: The Changing Roles of Scientific and Alternative Medicine', in David, P. and M. Thomas (eds.). The Economic Future in Historical Perspective, Oxford: Oxford University Press.

Geffen, N. 2005. 'Echoes of Lysenko: State-Sponsored Pseudo-Science in South Africa'. Social Dynamics, 31(2): 183-210.

Henderson, P. 2005. 'A Gift without Shortcomings: Healers Negotiating the Intersection of the Local and Global in the Context of HIV/AIDS', Social Dynamics, 31(2): 24-54.

Jordanova, L. 1995. 'The Social Construction of Medical Knowledge', Social History of Medicine, 8(3): 361-81. 
Levin, A. 2005. AIDSAFARI: A Memoir of My Journey with AIDS, Cape Town: Zebra Press.

Mall, S. 2005. Attitudes of Health Care Professionals to the use of Traditional Medicine by their Patients on Antiretroviral Treatment: A Research Note. Social Dynamics, 31(2): $118-125$.

Marks, S. 1997. 'What is Colonial about Colonial Medicine? And What has Happened to Imperialism and Health?', Social History of Medicine, 10(2): 205-19.

McGregor, L. 2005. Khabzela: The Life and Times of a South African, Johannesburg: Jacana Media.

Mills, E. 2005. HIV Illness Meanings and Collaborative Healing Strategies in South Africa, Social Dynamics, 31(2): 126-160.

Mills, E., Cooper, C., Seely, D., and I. Kanfer. 2003. 'African herbal medicines in the treatment of HIV: Hpoxis and Sutherlandia: An Overview of Evidence and Pharmacology', Nutrition Journal, 4(19): 2-6.

Nattrass, N. 2005. Who Consults Sangomas in Khayelitsha? An Exploratory Quantitative Analysis. Social Dynamics, 31(2): 161-182.

Nattrass, N. 2006a. 'What determines cross-country access to antiretroviral treatment?', Development Policy Review, May (forthcoming).

Nattrass, N. 2006b. AIDS, Science and Governance: The Battle over Antiretroviral Therapy in Post-Apartheid South Africa. Mimeo. Available on www.aidstruth.org. Forthcoming CSSR Working Paper.

Nattrass, N. 2006c. South Africa's 'rollout' of Highly Active Antiretroviral Therapy: A Critical Assessment'. Forthcoming CSSR Working Paper.

Porter, R. 1997. The Greatest Benefit to Mankind: A Medical History of Humanity from Antiquity to the Present. London: Harper Collins.

Ranger, T. 1981. 'Godly medicine, the ambiguities of medical mission in Southeast Tanzania, Social Science and Medicine, 15, 1:261-77.

Thamm, Marianne (2005), 'Who killed Fana Khaba?', Fair Lady (November), reproduced on http://blogmark.co.za/?q=node/2711.

Vaughan, M. 1992. Curing their Ills: Colonial Power and African Illness, Palo Alto: Stanford University Press.

Vaughan, M. 1994. Healing and Curing: Issues in the Social History and Anthropology of Medicine in Africa, Social Science and Medicine, 7(2): 283-95.

Wreford, J. 2005a. 'Missing each other: Problems and potential for collaborative efforts between biomedicine and traditional healers in South Africa in the time of AIDS', Social Dynamics, 31(2): 55-89.

Wreford, J. 2005b. 'Sincedisa - We can help! - A Literature Review of Current Practice Involving Traditional African Healers in Biomedical HIV/AIDS Interventions in South Africa' Social Dynamics, 31(2): 90-117. 
Wright, P. and A. Teacher. 1982. 'Introduction', in Wright, P. and A. Teacher, (eds.). The Problem of Medical Knowledge: Examining the Social Construction of Medical Knowledge, Edinburgh: Edinburgh University Press.

\section{Notes}

Data for June 2005 available on

http://www.who.int/hiv/facts/20UNMETNEEDweb.jpg 